\title{
INTERNATIONAL FINANCIAL MARKETS AND DEVELOPMENT
}

\section{Author:}

Peter Wahl ${ }^{1}$

Affiliation:
${ }^{1}$ NGO World Economy,
Ecology and Developmen

\section{Correspondence to:}

Allan A. Boesak

e-mail:

boesak@mweb.co.za

\section{Postal address:}

Postnet Suite 285, Private

Bag X15, Somerset West

7130, South Africa

\section{Keywords:}

international financial markets; globalisation; monetary policy; casino economy; liquid capital

\section{Dates:}

Received: 21 Aug. 2008

Accepted: 10 June 2009

Published: 06 Nov. 2009

How to cite this article: Wahl, P., 2009,

'International

financial markets and development', HTS

Teologiese Studies/

Theological Studies 65(1),

Art. \#284, 4 pages. DOI:

10.4102/hts.v65i1.284

\section{This article is available}

at:

http://www.hts.org.za

\section{Note:}

Paper presented at a meeting of the Joint

Globalization Task

Team of the Reformed

Churches of Germany

and South Africa, held at

Arnoldsheim, Frankfurt,

Germany, 26-30 May 2008.

\section{(C) 2009. The Authors.} Licensee: OpenJournals Publishing. This work is licensed under the Creative Commons Attribution License.

\section{ABSTRACT}

The current financial crisis has not come about by chance. It is the result of a system that has emerged over the last 30 years and which Keynes may well have called the 'casino economy'. The dominance of finance over real economy characterises the financial crisis, while finance itself is dominated by the all-encompassing target of maximum profit at all times. Other aims of economic activity such as job creation, social welfare and development have fallen by the wayside. In response, new actors are surfacing, e.g. the institutional investor (hedge funds, private equity funds, etc.), while new instruments are leading to highly leveraged and destabilising derivatives. The casino system has been promoted by governments and intergovernmental institutions to liberalise and deregulate financial markets. Although developing countries have not participated in the casino system, they have been suffering most from the spill-over into the real economy. The main lesson learnt is that the casino has to be closed.

Toward gold throng all,

To gold cling all, yes all! Alas, we poor!

Faust, J.W. von Goethe

\section{INTRODUCTION}

Africa is rich. As far as certain indicators of wealth development are concerned Africa is even considered to be a world leader, as is the case in terms of the increased growth rate of high net worth individuals. High net worth individuals are persons with liquid capital (not counting real estate, real values and luxury goods) of 1 million USD or more. In 2005, 8.7 million people worldwide belonged to this group. This group does not appear in current statistics as, numerically, it is too small. Usually it vanishes statistically in the upper 5 to $10 \%$ of the population. From 2004 to 2005 the number of African high net worth individuals showed the largest increase worldwide, i.e. 11.5\% (Capgemini/Merrill Lynch 2006; World Wealth Report 2006). In absolute figures their fortune increased by 51.5 billion USD, compared to a total amount of foreign aid of 24.7 billion USD official development assistance for the entire African continent). According to the Organisation for Economic Co-Operation and Development, of the 24.7 billion USD, 15.7 billion fell to Northern Africa, and the rest to sub-Saharan Africa (see Organisation for Economic Co-Operation and Development Factbook 2006). That is about half of high net worth individuals' capital gain.

The main factors for this development are global economic growth and the continent's growing integration into international financial markets. The capital yield at the Johannesburg Stock Exchange (JSE) was $43 \%$ in 2005, in third place after Seoul and Warsaw. But the problem remains: Only about 87000 Africans, i.e. less than $0.01 \%$ of the total population, benefit from this kind of growth. Africa is still poor. At present, more than half of the people on the continent survive on less than 1 USD a day. The World Bank (2007:79) predicts that by 2030, more than three-quarters of the population of sub-Saharan Africa is likely to be among the world's poorest'. The effects of poverty and wealth are not independent processes, but interrelated. Those talking about poverty cannot remain silent about wealth. An important correlation between poverty and wealth concerns financial markets, and in the move towards globalisation this is getting to be even more important.

\section{GLOBALISATION CENTRED ON FINANCIAL MARKETS - A HISTORIC TRANSFORMATION}

At first, financial markets had three main functions, i.e. to:

- organise international monetary transactions (foreign currency market)

- finance investments (credit market)

- facilitate bond trade (shares and government bonds) (bond market).

Subsequently, in relation to real economy - which means production and trade - financial markets had a secondary or subservient position. The three market segments were largely separated from one another. Before the 1970s financial markets were mainly national markets, thus concentrating on the prevailing national economy. Foreign trade only related to monetary transactions and foreign investments.

Moreover, until the 1970s international financial markets were regulated politically by the Bretton Woods system, which at its core promoted stable rates of exchange between important currencies and the control of capital transactions. This system provided a relatively stable general framework for the world economy, as well as considerable growth.

In 1973, when the above system came to an end, a radical change of historical impact began in the world economy. Stable rates of exchange were replaced by free ones, which meant fluctuating rates of exchange owing to supply and demand on foreign currency markets. Control of capital transactions was largely abolished and was replaced by the liberalisation and deregulation of capital circulation. Capital became the most mobile of all production factors. Today, along with technological progress (digitalisation, communication, etc.), by a click of the mouse billions of dollars may be transferred in a few seconds to any financial institution across the globe. In comparison with other production factors, 
money thus has a comparative advantage - and should be used as such.

Financial markets were not limited in terms of individual national economies, but were opened internationally and globally. At the same time, business size and variety grew by scales. Proportions between real economy and financial systems became inverted, which led to the economic dominance of the financial markets, creating the trigger, centre and motor for the present wave of globalisation.

\section{GENESIS OF NEW AND HIGHLY LUCRATIVE SOURCES OF YIELD}

By forming transnational financial markets, completely new and above-averagely high sources of yield were found.

- By arbitrage ${ }^{1}$ and speculation, trade with foreign currency - until then merely a subordinate service for trade and investment - became a source of yield of its own. Loss of control over capital transactions made arbitrage of interest abroad and speculation with bonds possible. For example, if capital interest rates were at $8 \%$ in the USA and at $16 \%$ in Brazil, it would be possible to raise debts of $8 \%$ in the USA, while this could be allocated as credit at an interest of $16 \%$ in Brazil. The difference between the costs of interest in the USA and the income from interest in Brazil relates to yield. In economic jargon this is called 'carry trade'. If this happens at a large scale, it could affect the entire country's interests and exchange rates. Keynes has referred to such a financial system as the 'casino system'.

- Another basic new process is securitisation. Credits, which used to be a bilateral business between creditor and debtor are being transformed into bonds and traded on the market, i.e. bought and sold deliberately. Thus the credit risk is distributed among other market participants. The latest example is the transformation of sub-prime mortgages ${ }^{2}$ in the USA into bonds for trading. The market, being a third factor, steps into the classic 'relationship' between bank and debtor. This radical change has consequences especially for financing enterprises, because large enterprises are no longer financed by their bank but by financial markets.

- As every fluctuation in the rates of exchange or other rates provides room for speculation, every opportunity is used for permanent purchases and sales. Subsequently, the capital volume of traffic increases dramatically. This leads to foreign-currency market transactions of 2 trillion USD every market day.

- A general trend to the short term, i.e. to quick yield, results. More than $80 \%$ of financial market investments have a runtime of a maximum of seven days. This leads to increased instability and delicacy of crises.

- At the same time, new financial products result, i.e. derivatives (Latin: derivare = descending, originating). Originally, derivatives were a type of insurance instrument based on real economic business. For example, by buying a debt the buyer takes up risks, not only because the debtor may become insolvent - that is the classic credit risk - but in the new system also because the paper's rate may have decreased at the time of re-sale. To protect against this, buyers do futures trading, i.e., they agree with the trader of a derivative to sell the debt at a fixed date and at a fixed price. The contract on this deal is called futures. The risk of reselling falls to the trader of the derivatives. In the meantime, new derivatives were being invented for various businesses, e.g. for development of rates (from rates of exchange to shares

1.Arbitrage is the exploitation of known exchange rate differences, i.e., if the exchange rate between the euro and the dollar is quoted differently at the close of the market in the European time zone than at the opening at Wall Street, the difference will be in the European time zone

2.Sub-prime means that generally not creditworthy debtors get credit. As the credito knows about this credit's insecurity, through securitisation he relocates the risk to the buyers of the new bond. up to aggregated indicators such as the Dow Jones or Dax). Trade is subject to control only up to $20 \%$, effected at the stock exchange. The remaining $80 \%$ is over the counter and completely uncontrolled. This trade of derivative obscurity makes it a factor of high risk on financial markets.

These earns, made possible through the system, rank above most earns that are generally obtained in real economy, i.e. about twice as much. Usually, they can also be realised in shorter periods of time. The leaders in this field, e.g. the Deutsche Bank, have obtained an own capital yield of $25 \%$, a margin which allows for doubling own capital invested in approximately three years. This leads to actors who have liquid capital at their disposal placing it preferably in new financial market businesses, as earns there are normally higher than in trade and production. In turn, this results in a structural weakness of investments with corresponding negative consequences for growth and employment.

A new economic system has emerged focused on financial markets and on replacing Rhenish Capitalism (Rheinischer Kapitalismus), with social partnership, full employment and welfare for everyone.

\section{NEW ACTORS - THE INSTITUTIONAL INVESTORS}

The dynamics of the financial markets have brought new actors to the game. Institutional investors are of prime importance here. They include banks, pension funds, insurance funds, investment funds, hedge funds, private equity funds, real estate investment trusts, etc. These actors appear as a central melting pot and, in combination with their own resources, place large amounts in financial business. Insurance and pension funds play a leading role in this. British pension funds move sums to the amount of one and a half of Great Britain's GDP in this way.

Unlike individual investors, they all have an enormous amount of capital at their disposal, including professional management staff for their investments.

The latest results of institutional innovation include hedge funds, private equity funds and real estate investment trusts. While banks, insurance and pension funds still operate in their traditional business branch and thus produce a value for the national economy, hedge funds, private equity funds and real estate investment trusts only concentrate on increasing shareholders' fortunes. The value for the national economy produced by this branch is merely an increase of the value itself. In business it is no longer enough to make a 'proper' profit. The only thing that matters seems to be the highest yield possible. International competition helps to make this an international trend.

Thus, new funds and business models incorporate the function of ownership exclusively. Their performance takes place in a professionalised form, i.e., they look for every suitable option to increase yield and use it in an institutionalised way, ensuring an approach that is more systematic than before.

Institutional investors transfer their focus on shareholders to the real economy. Another example is Deutsche Telekom (German Telecom) where the hedge fund Blackstone introduced wage cuts among heavy resistance from trade unions, even though the company is in the black. The planned yield can only be realised by strategies for lowering costs, which involve wage cuts, reduction of social security benefits, extension of working hours without wage adjustment, and reduction of or withdrawal from sharing of costs on social security systems. Other corporate aims such as growth, improvement of competitiveness by innovation and increase in production move to the background.

Competition forces enterprises that are not controlled by institutional investors to similar strategies in order to lower 
cost. Moreover, management's behaviour is influenced towards a new type of accumulation by corresponding triggers, for example paying off a main part of the salary as option paper and high compensations.

\section{POLITICAL SAFEGUARDING OF TRANSFORMATION}

However, it is not only the private sector that is part of this radical change. In the political and governmental spheres, the process of transformation has been and is being promoted by appropriate national laws (deregulation, tax cuts, etc.), international agreements and the politics of multilateral organisations. State, parliament and government are not helpless victims of change.

Atgovernment-institutional level,importantcomponents include offshorecentres(OFCs) and taxhavens. Theseareterritories where the usual economic, financial and tax legislations do not apply or apply only in part. Many of them are jurisdictions that depend on large states (Jersey, Bermuda Islands, Dutch Antilles, etc.) and have been created by government acts. Some of them are subjects of international law - albeit 'operetta states' such as Liechtenstein and Monaco. The largest OFC is the City of London, followed by Switzerland. OFCs are not marginal. The liquid resources being invested there are estimated at 2.7 trillion USD (2004), which is about $20 \%$ of the capital held in bank accounts worldwide. OFCs serve the financial markets' operators there in that they offer escape from financial supervision, avoidance of taxes (more or less legally) and money laundering opportunities for criminal and dubious purposes. Such policies pose a risk to the stability of the entire system. Another component is the multilateral financial situation, including the International Monetary Fund, the World Bank, the World Trade Organisation (through the treaty on financial services within the General Agreement on Tariffs and Trade), the Bank for International Settlements, the European Central Bank, the European Investment Bank and other regional investment banks. The International Monetary Fund, the World Bank and the European Central Bank, in particular, play a leading role in the enforcement of liberalisation and deregulation in the financial sector. With the conditions to adjust structures - which developing countries that are in debt have to fulfil when applying for public and private capital - the door to enforce economic orientation towards financial markets has been opened.

Rating agencies, which may be regarded as some form of privatised regulatory authorities, have promoted the herd instinct in the past. In fact, they did play a preventive role in any of the big crashes.

At a national level, most governments aim at a politic which meets the interests of the financial markets' operators. The combination of hegemony of the neo-liberal discourse, lobbyism of the financial industry and practical constraints arising from the economy's transnationalisation and international competition, have led to governmental politics being particularly equalised to the financial markets.

\section{EFFECTS}

The effects of transformation processes on the financial markets of developing countries are visible in three main areas: Risks of stability, social polarisation and erosion of democracy.

\section{Risks of stability}

At the end of the Bretton Woods system, volatility (intensity of fluctuation) and systematic instability increased dramatically, while financial crises and crashes became more evident. Substantial elements of instability are exchange rate volatility, short-time orientation, high-risk funds offshore centres, derivatives, pro-cyclic behaviour ('herd instinct') of financial markets' operators, and the international risk of infection with crises. This is also becoming evident in the latest financial crisis, which has been caused by the breakdown in US markets for subprime mortgages, which involved the Saxon State Bank and other German banks. The national economies of developing countries and newly industrialising countries are especially vulnerable in this instance. The crisis in the financial sector subsequently spread to the economy.

Because of the crisis in Asia, many middle-class enterprises and smaller companies had to declare bankruptcy. This led to a fall in consumption demand, mass unemployment, wage cuts and impoverishment. Following the 2001 crash, more than half of Argentina's population are living below the poverty line.

Not only the countries in which the crash happens are concerned, but also indirectly others. For example, after the crisis in Thailand, the collapse in Laos was even bigger because $80 \%$ of this country's foreign trade is influenced by Thailand.

Even if there is no impending crisis and financial markets are functioning properly, the volatility and pace on these markets mean permanent economic stress and expenses for developing countries.

Exchange rate instability leads to instability in foreign trade proceeds and debt settlements. International trade and debt settlements are handled partly in dollar and partly in other hard currencies. Any fall in the dollar exchange rate leads to increases in the price of exports and therefore to a fall in competitiveness on world markets. At the same time, debt settlement and the invoice amount on oil fall in respect of oil-importing countries. All in all, this leads to an unstable and unpredictable economic environment.

Enterprises can protect themselves against this insecurity to some extent by taking out insurance on exchange rate risks ('hedging', not to be mistaken for hedge funds). But this involves costs. Because the currencies of developing countries are often more instable than the hard currencies of developed countries, their foreign trade becomes dearer proportionally. The determinants for exchange rate risk in trade and investments are not the short term changes (the exchange rates are being registered every second), but rather the monthly or quarterly fluctuations because they seem to influence decisions in terms of consumption and investments. On the other hand, daily fluctuations pose a major problem for debt settlement.

Another method to lower the instability of exchange rates is to collect currency reserves to stabilise own currencies. The disadvantage of this procedure is that it is very expensive. A constant outlet of means arises which can be several times higher than the amount of foreign aid. Another disadvantage is this instrument's absorption of enormous means which cannot be planned for in terms of development and the fight against poverty.

In addition, there is the risk that devaluation of currencies (in which the reserves are kept) will lead to corresponding losses and that large reserves will exert pressure in terms of raising interest rates. This type of protection of the exchange rate risk is extremely inefficient and a long-term obstacle for development.

\section{Social polarisation}

As far as distribution is concerned, the new system leads to social polarisation, which means that development of income and capital formation are extremely dynamic in the higher and top levels, while decreasing in the lower levels, and ending in stagnation or retreat. This applies to industrialised countries as well as developing countries. The cake is getting larger, and the slice which goes to the powerful and the rich is increasing, while the rest end up with much smaller portions.

The effects of redistribution from bottom to top not only arise from direct income from purchase and wealth. Tax politic usually 
contributes to social polarisation. To increase the own country's attractiveness as a financial location, financial investors are attracted through tax relief. Financial markets use their political influence to lower direct taxes (income tax, corporation tax and wealth tax) and to increase indirect taxes (consumption tax). This leads to tax regression, which means that the relative charging of the lower classes increases and tax justice erodes.

There are also problematic effects for important social securing systems in terms of distribution arising from the dynamics of financial markets. Liberalisation and deregulation in this sector have led to insurance and pension funds of the industrialised countries pushing into newly industrialising countries and developing countries to sell health and old-age insurance to the middle class. This results in the removal of the basis for setting up social securing systems. The systems of solidarity that arose in the second half of the 1900s reflected progress in civilization which, for the first time in human history, made it possible for subaltern classes to gain some kind of insurance against life's vicissitudes. This was based on social alliance with the middle classes by which the system of redistribution from top to bottom - typical of systems of solidarity - was financed.

\section{Erosion of democracy}

Money does not only have an economic dimension. Disposal over large sums can be used as a powerful means of gaining political influence. The financial markets' political economy has to consider their effects in areas other than the economy. According to Aristotle: 'The real difference between democracy and oligarchy is between poverty and wealth' (see PhillipsSimpson Keynes 1997:82). This also applies in terms of the conditions of a parliamentary democracy. According to section 28 of the Universal Declaration of Human Rights of 1948: 'Everyone is entitled to a social and international order in which the rights and freedoms set forth in this Declaration can be fully realised' (see Ishay 2007:55). The main challenge lies in the fact that, in addition to transnationalisation of the economy, transnational areas are building up which evade them from the single nation's regulatory access. Parliamentary democracy is inseparably connected to the territorial principle of the nation state historically and structurally (Habermas 1992:446). The national territory and resident citizens form the basis of the democracy, whereas transnational areas evade them from any democratic control.

Therefore there is no democracy beyond the nation state. In particular, this relates to financial markets and transnational enterprises, the decisions of which often impact the fate of millions of people. The effect of this on the governments of nation states tends to be the erosion of their democracy. Following Montesquieu's theory of the separation of powers, the former boss of one of the largest global players in the financial markets attributed the role of the fifth power to them. Besides the legislative, executive and judicative, Montesquieu regards the media as the fourth power, and the financial markets as the fifth (Laffont \& Martimort 1999:232). Many political decisions are enforced through official decisions on investments which are influenced by competitive economical considerations: 'As a result of greater exit option enjoyed by capital, government policies have now become hostage to financial markets' (Yilmaz Akyüz, UNCTAD's former head economist).

Parallel to this, social polarisation and impoverishment often contribute to political destabilisation because they favour xenophobia, racism and religious fanaticism.

\section{ALTERNATIVES}

It is decisive for reform that financial markets are again subject to political and democratic control. Financial markets have to be there for people, not the other way round. They especially have to serve development and assist in the fight against poverty.
Along the way, numerous single steps could be introduced, i.e.:

- Introduction of a tax on foreign currency transactions

- Tax on stock exchange sales

- Abolition of tax privileges for capital gains and progressive taxation

- Control over capital transactions

- Stabilisation of exchange rates, e.g. by creating regional monetary unions such as the Euro Area

- Neutralisation of OFCs

- Prohibition of high-risk hedge funds

- Prohibition of over the counter derivatives

- Social and development-focused regulation of private equity funds and real estate investment trusts

- Democratisation of international financial institutions, such as the International Monetary Fund, the World Bank, and the European Investment Bank

- Democratic control of the European Central Bank and the Bank for International Settlements (Union of the Central Banks in Organisation for Economic Co-Operation and Development countries)

- Improvement of financial supervision and international cooperation of supervisory bodies and in investigation of tax evasion

- Transfer of rating agencies to public management.

\section{REFERENCES}

Habermas, J., [1989] 1992, The structural transformation of the public sphere: Inquiry into a category of bourgeois society, MIT Press, Cambridge.

Ishay, M.R. 2007, The human rights reader: Major political essays, speeches and documents from ancient times to the present, 2nd edn., Routledge, New York.

Organisation for Economic Co-Operation and Development Factbook, 2006, 'Economic, environmental and social statistics', viewed 4 September 2009, from www.oecd.org/.. /0,3425,en_2649_37463_34582591_119656_1_1_1,00.html.

Phillips-Simpson Keynes, P.L. 1997, The politics of Aristotle, University of North Carolina Press, Chapel Hill.

World Bank, 2007, Global economic prospects. Managing the next wave of globalization, World Bank, Washington. 